\title{
Capital Structure Conditions Affected by Company Internal Factors: a Case Study of Non-Cyclicals Consumer Companies on Indonesian Stock Exchange
}

\author{
Isnaeni Rokhayati ${ }^{1}$, Nirmala ${ }^{2}$, Wisnia Trias Oktaviani ${ }^{3}$ \\ ${ }^{123}$ Faculty of Economics and Business, Wijayakusuma University, Purwokerto \\ Correspondence Email: isnaeni_akbar@yahoo.co.id
}

\begin{abstract}
The purpose of this research is to find out how the variables of firm size, asset structure, profitability, liquidity, and sales growth influence the capital structure of non-cyclical consumer companies listed on the Indonesia Stock Exchange. The population in this study was 55 non-cyclical consumer companies listed on the Indonesia Stock Exchange in 2015 - 2019 , while for the method of determining the sample in this study using a purposive sampling technique, as many as 25 companies. The analytical technique used is multiple linear regression analysis with panel data using the Eviews 9 program. The results show that the variables of firm size, asset structure, profitability, liquidity and sales growth have a negative and significant effect on capital structure. These results indicate that the variables of firm size, asset structure, level of profitability, liquidity and sales growth have increased, it will cause the level of the company's capital structure to decrease. Contribution to this research is expected that the company can increase company size, asset structure, profitability, liquidity and sales growth so that the use of debt in the company's capital structure decreases. This study only examines five independent variables, namely firm size, asset structure, profitability, liquidity, and sales growth. This study focuses only on examining Consumer Non-Cyclicals companies listed on the Indonesia Stock Exchange (IDX). Future research is expected to be able to add other variables that affect the capital structure by using company external variables such as taxes, economic conditions, interest rates with research objects in other companies, as well as with a longer research period so that the results obtained can be generalized.
\end{abstract}

Keywords: Capital Structure, Company Size, Asset Structure, Profitability, Liquidity, Sales Growth.

\section{Introduction}

Currently in the era of globalization has brought intense competition in the business world. To be able to face global competition, companies are faced with making financial decisions, namely funding decisions and investment decisions (Tangiduk et al., 2017). Funding decisions are important for companies in facing business competition, where companies are required to be able to maintain the availability of company funds. Funding is used, among others; support the company's operational activities, carry out company development, and invest. The need for corporate funding has resulted in the company being faced with the problem of determining the optimal capital structure to carry out the company's overall operational activities. Optimal capital structure plays an important role in achieving the company's goals to carry out daily operational activities of the company and can reflect the company's financial condition and affect the survival of a company (going concern). The company's capital structure can be obtained from own capital, long-term loans from creditors, sale of shares to investors, and retained earnings. The average company in Indonesia prioritizes the capital structure sourced from long-term loans from creditors (Rohmiyati et al. 2018).

The object of this research is non-cyclical consumer companies, which are consumer goods companies whose stocks are defensive or whose stock movements are not affected by economic conditions because the goods produced are goods for the community. This sector company sells the needs of the community, such as instant noodles, snacks, toothpaste, soap, etc. Although the shares of this non-cyclical consumer sector company are defensive, it does not mean that this company has an optimal capital structure. This means that the company's capital structure is always changing related to the level of change in capital requirements in the company. This change in capital structure is identified to be influenced by internal company factors that can be seen in the company's financial statements for each reporting period. Previous researchers have conducted research on factors that can affect the capital structure, among others; Shil et al. (2019), Dakua (2018), Jarallah et al. (2018), Wang et al. (2018), Matias and Serrasqueiro (2017) which explain that company size, profitability and liquidity have a significant negative effect on capital structure. Meanwhile, other studies that explain the factors that influence the capital structure have different results, among others, carried out by; Cahyani \& Isbanah (2019), Lestari \& Purnawati (2018), Pertiwi \& Darmayanti (2018), Effendi \& Nugraha (2018), Hudan et al. (2016), Yunita \& Aji (2018), Guna \& Sampurno (2018), Deviani \& Sudjarni (2018), Lestari et al. (2019), Prabowo et al. (2018), Lasut et al. (2018), Andayani \& Suardana (2018), Rohmiyati et al. (2018), Setiyanti et al. (2019).

The explanation from previous research is that there are several factors that affect the capital structure, namely, company size, asset structure, profitability, liquidity, sales growth, dividend policy, and business risk. From 
the results of previous studies, it is explained that there are variables that have different influences, including; firm size, asset structure, profitability, liquidity, and sales growth variables. Based on the differences in the results of previous studies, it is possible for researchers to re-examine the company's internal factors that can affect the company's capital structure. The purpose of this study is to determine and analyze what factors can affect the company's capital structure and the extent to which changes in the level of company's capital structure needs are financed using funding from external capital.

\section{Literature}

Pecking Order Theory was first introduced by Donalson (1961), while the planting of Pecking Order Theory was carried out by Myers (1984). This theory states that companies prefer internal financing, namely funding from the company's operating results in the form of retained earnings. If external financing is needed, the company will issue the safest securities first, namely bonds, then followed by securities with option characteristics and if funding is not sufficient, the company will issue new shares (Juwono, et al. 2013). The trade-off theory put forward by Myers (1984), explains that the company will be in debt to a certain level of debt, where the tax shields from additional debt equal the cost of financial distress (financial distress). The costs of financial distress are the costs of bankruptcy (bankruptcy costs) or reorganization, and agency costs that increase as a result of the decline in the credibility of a company. Trade-off theory in an effort to determine the optimal capital structure includes factors including taxes, agency costs and financial distress costs by maintaining the assumption of market efficiency and symmetric information as a balance and benefit of using debt. As long as the benefits obtained are greater, eating for additional debt is still allowed. If the sacrifice due to the use of debt is greater, then the addition of capital from debt is not allowed.

Riyanto (2011) explains that the company's capital structure can be calculated from the comparison between long-term debt and own capital. Capital structure is the composition of funds used to meet the company's investment needs consisting of debt, equity and other securities (Berk, Jonathan, and Harfoed 2012). The composition of the capital structure must be considered because the company's capital structure can show a picture of the financial condition of each company. The condition of meeting funding needs in the capital structure can affect investors who will invest in the company. Investors will be able to see the optimal condition of the company's capital structure from the company's published financial statements. Investors will use various analyzes of decision making in investing in the company through information sourced from the published financial statements of the company (Cahyani \& Handayani, 2017).

Brigham and Houston (2011), suggest that company size is a scale where the size of the company can be classified according to various ways, including; total assets, log size, stock market value, and market equity. Company size describes the size of a company. Companies with large company sizes will find it easier to get loans from outside, so they can improve their capital structure. In this study, the measurement of company size used is ln total assets. Research by Lestari \& Purnawati (2018), Lasut et al. (2018) shows that the firm size variable has an influence on the capital structure. While research by Guna \& Sampurno (2018), Lestari \& Purnawati (2018) shows that the firm size variable has no effect on capital structure. Asset structure is a determination of how much of the allocation for each component of assets, both current assets and fixed assets. Brigham and Houston (2011) explain that companies that have larger long-term fixed assets will use more long-term debt, because existing fixed assets can be used as debt collateral. In this study, the measurement of asset structure uses a comparison between fixed assets and total assets. In the research of Cahyani \& Isbanah (2019), Pertiwi \& Darmayanti (2018), Novyarni \& Wati (2018), it shows that the asset structure variable has an effect on capital structure while the research of Yunita \& Aji (2018), Wijaya \& Jessica (2017), Tangiduk et al. . (2017) the asset structure variable has no effect on the capital structure. Profitability or profitability is the company's ability to generate profits during a certain period. The profitability ratio will show the combined effects of liquidity, asset management, and debt on operating results. Companies with high profitability tend to use internal funds rather than debt, so the capital structure will decrease. Measurement of profitability using Return on Assets (ROA). Andayani \& Suardana (2018), Wirawan (2017), Fatika et al. (2020) the profitability variable has a significant positive effect on the company structure. Meanwhile, in the research of Deviani \& Sudjarni (2018), Wijaya \& Jessica (2017), Ratri \& Christianti (2017) the profitability variable has a negative influence on capital structure.

Liquidity is the company's ability to meet short-term financial obligations in a timely manner. Liquidity is indicated by the size of current assets, namely assets that are easily converted into cash. Liquidity includes cash, marketable securities, inventories, and accounts receivable Sartono (2014). The higher the level of company liquidity, the capital structure will decrease. Liquidity measurement uses current ratio or Current Ratio (CR). Research by Lestari \& Purnawati (2018), Pertiwi \& Darmayanti (2018), Yunita \& Aji (2018) liquidity has a negative effect on capital structure. In the research of Dakua (2018), Ratri \& Christianti (2017), liquidity has a positive effect on capital structure. Sales growth is the company's ability to increase the company's sales turnover. With high sales growth, the company will get a high level of profit, this can improve the company's financial performance. When sales growth 
increases, the company will get increased profits so that the use of debt is reduced and the capital structure decreases. In this study, the measurement of sales growth used is Sales Growth. Research by Deviani \& Sudjarni (2018), Ratri \& Christanti (2017) explains that sales growth has a negative effect on capital structure. Meanwhile, in the research of Setiyanti et al. (2019), Asmas et al. (2018) sales growth has a positive effect on capital structure.

\section{Method}

This type of research is quantitative research using secondary data in the form of published company financial reports, while the object of research is non-cyclical consumer companies listed on the Indonesia Stock Exchange in 2015-2019. The dependent variable in this study is the capital structure. While the independent variables are company size, asset structure, profitability, liquidity and sales growth. The population in this study were 55 companies. Determination of the research sample using purposive sampling technique obtained a sample of 25 companies. The research analysis method used is panel data regression analysis with the help of software eviews 9 . The best model obtained from this study is the common effect model.

\section{Results}

Based on the results of data analysis with panel data regression using the help of the Ewiews 9 program, the following results can be obtained, that company size has a negative and significant effect on capital structure. It can be seen in the tcount value of -2.271455 which is smaller than the -ttable value of -1.65776 with a probability level of 0.0249 which is smaller than $=0.05$. This shows that the higher the size of the company, the lower the level of the company's capital structure. Companies that have a high company size indicate that the number of assets owned by the company increases, it can be seen by the addition of company assets in the form of fixed and current assets. With the high size of the company, the capital structure decreases, this is because the company has a lot of current assets to meet the company's funding needs so that external debt decreases and the capital structure decreases. The results of this study in accordance with the Pecking Order Theory are that companies are more likely to prefer funding from internal sources than from external debt (Lestari and Purnawati, 2018). The results of this study are in line with research conducted by Lestari \& Purnawati (2019), Effendi \& Nugraha (2018), Hudan et al. (2016), and Rohmiyati et al. (2018), shows the results that the firm size variable has a negative and significant effect on capital structure.

The results of the analysis show that the asset structure variable has a negative and significant effect on the capital structure. It can be seen from the tcount value of -4.409458 which is smaller than the -ttable value of -1.65776 with a probability level of 0.0000 which is smaller than $=0.05$. This shows that if the level of asset structure increases, the use of company debt will decrease. These results indicate that the higher the structure of the company's assets measured by the fixed assets owned by the company, the additions such as the purchase of buildings, the addition of machines. This causes the level of use of the capital structure to decrease with the addition of fixed assets and companies tend to reduce the use of external funding. The use of external funding sources or debt is only used when internal funding is insufficient (Tangiduk et al. 2017). When the company has high fixed assets, it does not guarantee an increase in the company's capital structure. The results of this study are in line with research conducted by Cahyani \& Isbanah (2019), and Dakua (2018) showing the results that the asset structure variable has a negative and significant effect on capital structure. Profitability variable has a negative and significant effect on capital structure. It can be seen from the tcount value of -2.058134 which is smaller than the -ttable value of -1.65776 with a probability level of 0.0215 which is smaller than $=0.05$. The results of this study indicate that profitability has a negative and significant effect on the capital structure of non-cyclical consumer companies listed on the Indonesia Stock Exchange. When the company has a high level of profitability due to an increase in sales, then the company has a number of available profits to meet its needs by using the company's internal funds so that the use of debt is not needed or it can be interpreted that the company's capital structure decreases because the company does not add debt. The results of this study are in line with the research conducted by Hudan et al. (2016), Deviani \& Sudjarni (2018), Wijaya \& Jessica (2017), Asmas et al. (2018), Irdiana (2016), Ratri \& Christianti (2017), which show that the profitability variable has a negative effect on capital structure.

The analysis shows that the Liquidity variable has a negative and significant effect on the capital structure. It can be seen from the tcount value of -9.819666 which is smaller than the -ttabe value of -1.65776 with a probability level of 0.0000 which is smaller than $=0.05$. The results showed that liquidity had a negative and significant effect on capital structure. These results indicate that the higher the level of liquidity of a company, the company's capital structure will be lower. The company's high level of liquidity indicates that the company has adequate internal financial capabilities to meet short-term obligations that have an impact on the capital structure (Deviani \& Sudjarni, 2018). High liquidity indicates that current assets owned by the company in the form of cash, receivables and inventories are increasing. Where the company has more internal funds, it tends to use internal funds compared to using debt, resulting in a decreased capital structure. This is in accordance with the pecking order theory. The results of this study are in line with research conducted by Lestari \& Purnawati (2018), Pertiwi \& Darmayanti (2018), Hudan 
et al. (2016), Yunita \& Aji (2018), Guna \& Sampurno (2018), Deviani \& Sudjarni (2018) which show that liquidity has a negative and significant effect on capital structure. The research analysis shows that the sales growth variable has a negative and significant effect on the capital structure. It can be seen from the t-count value of -2.330427 which is smaller than the $-\mathrm{t}$-table value of -1.65776 with a probability level of 0.0215 which is smaller than $=0.05$. The results showed that sales growth had a negative and significant effect on capital structure. This condition indicates that the higher the sales growth rate of a company, the use of the company's capital structure will decrease. Companies with increasing sales levels cause profit levels to also increase. So that the company will finance with profit and will reduce the use of debt, this condition is in accordance with the pecking order theory (Prabowo et al. 2018). The results of this study are in line with research conducted by Cahyani \& Isbanah (2019), Guna \& Sampurno (2018), Deviani \& Sudjarni (2018), Ratri \& Christianti (2017), Irdiana (2016) which shows that sales growth has a negative and significant effect. to the capital structure.

\section{Conclusion}

The results of the study explain that the variables of firm size, asset structure, profitability, liquidity, and sales growth have a negative and significant effect on capital structure. Where if the size of the company, the level of asset structure, level of profitability, level of liquidity and growth rate have increased then the level of capital structure will increase. The company is expected to always increase the assets owned by the company, both fixed assets and current assets so that the company will be able to reduce the use of debt in its capital structure. The use of funding from the company's internal sources is prioritized to reduce loans so as to avoid the risk of debt default. Further research is suggested to use other variables that affect the capital structure such as including the company's external variables such as: taxes, economic conditions, and interest rates.

\section{References}

Andayani, I. A., \& Suardana, K. A. (2018). Pengaruh Profitabilitas, Likuiditas, Pertumbuhan Penjualan, dan Struktur Aktiva Pada Struktur Modal. E-Jurnal Akuntansi Universitas Udayana, 24, 370-398.

Asmas, D., H., \& Adisetiawan, R. (2018). Struktur Modal dan Variabel yang Mempengaruhinya. J-MAS (Jurnal Manajemen dan Sains), 3(2), 237-250.

Batubara, R, A, P., T., \& Z.A., Z. (2017). Pengaruh Struktur Aktiva, Ukuran Perusahaan, dan Profitabilitas Terhadap Struktur Modal (Studi Pada Perusahaan Makanan Dan Minuman Yang Terdaftar Di Bursa Efek Indonesia Tahun 2012-2015). Jurnal Administrasi Bisnis (Jab), 50(4), 1-9.

Berk, Jonathan, and Peter Demarzo and Jarrad Harfoed. 2012. Fundamentals of Corporate Finance. Second Edi. Boston, Massachussetts: Prentice Hall.

Brigham, Eugene F and Joel F.Houston, 2011. Dasar-Dasar Manajemen Keuangan, alih bahasa Ali Akbar Yulianto, Buku dua , Edisi sebelas, PT. Salemba Empat, Jakarta.

Cahyani, I. D., \& Isbanah, Y. (2019). Pengaruh Struktur Kepemilikan, Tangebility, Firm Age, Business Risk, Kebijakan Dividen, dan Sales Growth Terhadap Struktur Modal Sektor Properti Real Estate yang Terdaftar Di Bei Periode 2012-2016. Jurnal Ilmu Manajemen, 7, 124-132.

Cahyani, N. I., \& Handayani, N. (2017). Pengaruh Profitabilitas, Likuiditas, Size , Kepemilikan Institusional , Dan Tangibility Terhadap Struktur Modal. Jurnal Ilmu Dan Riset Akuntansi, 6(2), 614-630.

Carnevela, Cindy R dan Nurul Widyawati. 2017. "Pengaruh Pertumbuhan Penjualan, Ukuran Perusahaan, dan Struktur Aktiva terhadap Struktur Modal". Jurnal Ilmu dan Riset Manajemen Vol. 6. No. 3. Hal 26- 38. STIESIA. Surabaya.

Dakua, S. (2018). Effect Of Determinants On Financial Leverage In Indian Steel Industry: A Study On Capital Structure. International Journal Of Finance \& Economics. doi:10.1002/ijfe.1671

Desmianti Tangiduk, P. V., \& Tumiwa, J. (2017). Analisis Pengaruh Ukuran Perusahaan, Struktur Aktiva, Dan Profitabilitas Terhadap Struktur Modal Pada Perusahaan Manufaktur Sektor Industri Dasar dan Kimia yang Terdaftar di Bursa Efek Indonesia Periode 2011-2015. Jurnal EMBA, 874-883.

Deviani, M. Y., \& Sudjarni, L. K. (2018). Pengaruh Tingkat Pertumbuhan, Struktur Aktiva, Profitabilitas, dan Likuiditas Terhadap Struktur Modal Perusahaan Pertambangan di BEI. E-Jurnal Manajemen Unud, 7(3), 1222-1254.

Dewi, H, S., A. T., \& Hottua Samosir, S. E. (2019). Pengaruh Sales Growth, Current Ratio, Firm Size dan Return On Assets Terhadap Struktur Modal Pada Perusahaan Consumer Goods yang Terdaftar di Bursa Efek Indonesia Tahun 2012-2016. Jurnal Ekonomi \& Ekonomi Syariah, 2(2), 1-16.

Effendi, M., \& Nugraha. (2018). Return On Assets, Likuiditas dan Ukuran Perusahaan Terhadap Struktur Modal. Jurnal Ekonomi dan Bisnis, 2(1), 44-54. 
Isnaeni Rokhayati et al., Capital Structure Conditions Affected by Company Internal Factors: a Case Study of Non-Cyclicals Consumer Companies on Indonesian Stock Exchange

Guna, M. A., \& Sampurno, R. D. (2018). Analisis Faktor-Faktor yang Mempengaruhi Struktur Modal (Studi Kasus Pada Perusahaan Makanan Dan Minuman Yang Terdaftar Di BEI Periode 2012 - 2016). Diponegoro Journal Of ManagemenT, 7(2), 1-12.

Halim, Abdul. 2015. Manajemen Keuangan Bisnis. Bogor: Ghalia Indonesia.

Harahap, A. K., \& Irawan, A. E. (2018). Pengaruh Profitabilitas, Pertumbuhan Asset, dan Ukuran Perusahaan Terhadap Struktur Modal (Study Kasus Pada Perusahaan Realestate dan Property yang Terdaftar di BEI Tahun 2013 - 2015). Jurnal Bisnis Darmajaya, 4(1), 15-25.

Harmono. 2015. Manajemen Keuangan Berbasis Balanced Scorecard. Ed. 1, Cet.4. Bumi Aksara.s Jakarta

Hery. 2017. Kajian Riset Akuntansi. Jakarta. PT. Grasindo

Hudan, Y., D. I., \& Dedik Nur Triyanto.S.E., M. (2016). Pengaruh Profitabilitas, Likuiditas Dan Ukuran Perusahaan Terhadap Struktur Modal (Studi Pada Perusahaan Pertambangan Sektor Batubara Yang Terdaftar Di Bursa Efek Indonesia Tahun 2011-2015). e-Proceeding Of Management, 3(2), 1596-1603.

Irawan, S. M., \& Cahyo Pramono, S. M. (2017). Pengaruh Suku Bunga, Struktur Aktiva Dan Ukuran Perusahaan Terhadap Struktur Modal Dengan Moderasi Profitabilitas Pada Perusahaan Sektor Aneka Industri Di Bursa Efek Indonesia. Jurnal Manajemen Tools, 7(1), 45-56.

Irdiana, S. (2016). Analisis Faktor-Faktor Yang Mempengaruhi Struktur Modal Pada Perusahaan Katagori Saham Blue Chips Di Bursa Efek Indonesia Periode Tahun 2011-2014. Jurnal Penelitian Ilmu Ekonomi WIGA, 6(1), 15-26.

Ismaida, Putri, \& Saputra, Mulia. (2016). Pengaruh Pertumbuhan Penjualan, Profitabilitas, Ukuran, Dan Aktivitas Perusahaan Terhadap Struktur Modal Pada Perusahaan Property Dan Real Estate Yang Terdaftar Di BEI Periode 2012-2014. Jurnal Ilmiah Mahasiswa Ekonomi Akuntansi, 1(1), 221-229.

Jarallah, S., Saleh, A. S., \& Salim, R. (2018). Examining Pecking Order Versus Trade-Off Theories Of Capital Structure: New Evidence From Japanese Firms. International Journal Of Finance \& Economics. doi:10.1002/ijfe. 1657

Juwono, S., Abdurrahman dan L. Amalia. 2013. Deteksi Praktis Aplikasi POT (Pecking Order Theory). Jurnal Ekonomi 4(1): 13-28.

Kasmir. 2012. Manajemen keuangan teori, dan aplikasi. Yogyakarta.

Lestari, N. L., \& Purnawati, N. K. (2018). Analisis Pengaruh Kinerja Keuangan Terhadap Struktur Modal Pada Perusahaan Makanan Dan Minuman Di BEI. E-Jurnal Manajemen Unud, 7(7), 3564-3593.

Lestari, P, L., E., \& Faruk, M. (2019). Pengaruh Kinerja Keuangan Dan Ukuran Perusahaan Terhadap Struktur Modal (Studi pada PT. Mayora Indah Tbk. yang Terdaftar Di BEI Periode 2007-2017). Business Management and entrepreneurship Journal, 1(3), 185-200.

Maryanti, E. (2017). Analisis Profitabilitas, Pertumbuhan Perusahaan, Pertumbuhan Penjualan Dan Struktur Aktiva Terhadap Struktur Modal Pada Perusahaan Sektor Industri Barang Konsumsi Yang Terdaftar Di Bursa Efek Indonesia (Studi Empiris Pada Perusahaan Manufaktur yang Terdaf. Riset Akuntansi Dan Keuangan Indonesia, 1(2), 143.

Matias, F., \& Serrasqueiro, Z. (2017). Are There Reliable Determinant Factors Of Capital Structure Decisions? Empirical Study Of Smes In Different Regions Of Portugal. Research In International Business And Finance, 40, 19-33. doi:10.1016/j.ribaf.2016.09.014

Mirnawati, A. W., \& Siddi, P. (2020). Pengaruh Kebijakan Dividen, Likuiditas, Tangibility, Asset Turnover, Dan Company Growth Terhadap Struktur Modal. Jurnal Kajian Pendidikan Ekonomi dan Ilmu Ekonomi, 12-24.

Munawir, S. 2012. Analisis Laporan Keuangan. Edisi Kedua. Yogyakarta : BPFE.

Myers, S. C., \& Maljuf. (1984). Corporate Financing and Investment Decission When Firms Have Information Investor Do Not Have. Journal of financial Economic. (13), 187-221

Novyarni, N., \& Wati, L. (2018). Pengaruh Pertumbuhan Penjualan, Ukuran Perusahaan, Struktur Aset, Dan Profitabilitas Terhadap Struktur Modal Pada Perusahaan Manufaktur Yang Terdaftar Di Bursa Efek Indonesia Periode Tahun 2012-2015. Jurnal STEI Ekonomi, 27(2), 254-285.

Nurmadi, R. 2013. Analisis Faktor-faktor yang Mempengaruhi Struktur Modal Perusahaan Manufaktur. Jurnal Keuangan dan Bisnis, 5 (2):170-178.

Pertiwi, N. K., \& Darmayanti, N. P. (2018). Pengaruh Profitabilitas, Likuiditas, Struktur Aktiva dan Kebijakan Dividen Terhadap Struktur Modal Perusahaan Manufaktur Di BEI. E-Jurnal Manajemen Unud, 7(6), 31153143.

Prabowo, N., D. S., \& Harimurti, F. (2018). Pengaruh Profitabilitas, Pertumbuhan Aset, Likuiditas, Struktur Aktiva, dan Pertumbuhan Penjualan Terhadap Struktur Modal. Jurnal Akuntansi dan Sistem Teknologi Informasi, 447 $-457$.

Ratri, A. M., \& Christianti, A. (2017). Pengaruh Size, Likuiditas, Profitabilitas, Risiko Bisnis, dan Pertumbuhan Penjualan Terhadap Struktur Modal Pada Sektor Industri Properti. JRMB, 12(1), 13-24. 
Isnaeni Rokhayati et al., Capital Structure Conditions Affected by Company Internal Factors: a Case Study of Non-Cyclicals Consumer Companies on Indonesian Stock Exchange

Riyanto, B. 2001. Dasar-Dasar Pembelanjaan Perusahaan, Edisi Keempat, Cetakan Ketujuh, BPFE Yogyakarta, Yogyakarta.

Rodoni, A., dan Ali, H. (2011). Manajemen Keuangan. Jakarta : Mitra Wacana Media.

Rohmiyati, A. W., \& Nurlaela, S. (2018). Pengaruh Likuiditas, Profitabilitas, Firm Size dan Growth Terhadap Struktur Modal Pada Perusahaan Kimia Dan Farmasi. Jurnal Ekonomi Paradigma, 19(2), 113-122.

Salehudin. 2015. Pengaruh Struktur Aktiva dan Ukuran Perusahaan Terhadap Struktur Modal Pada Perusahaan Pertambangan yang Listing di BEI. Skripsi pada Program Studi Manajemen FE Unigal. Tidak diterbitkan

Sartono, Agus. 2013. Manajemen Keuangan Teori dan Aplikasi Edisi 4. Yogyakarta: BEF

Setyawan, A. I. W., Topowijono, \& Nuzula, N. F. (2016). Pengaruh Firm Size, Growth Opportunity, Profitability, Business Risk, Effective Tax Rate, Asset Tangebility, Firm Age dan Liquidity terhadap Struktur Modal ( Studi pada Perusahaan Sektor Property dan Real Estate yang Terdaftar di BEI Tahun. Jurnal Administrasi Bisnis, 31(1), 108-117.

Shil, N., Hossain, M. N., \& Ullah, M. N. (2019). Exploring The Underlying Factors Affecting Capital Structure Decision: A Quantitative Analysis. Journal Of Corporate Accounting \& Finance. doi:10.1002/jcaf.22404

Setiyanti, S. W., D. P., \& Pari, R. K. (2019). Pengaruh Profitabilitas, Ukuran Perusahaan, Struktur Aktiva Dan Pertumbuhan Penjualan Terhadap Struktur Modal Pada Perusahaan Manufaktur yang Terdaftar Di Bursa Efek Indonesia Periode 2012-2016. Jurnal STIE Semarang, 11(2), 15-30.

Seftianne. dan Ratih Handayani. 2011. Faktor-faktor yang mempengaruhi struktur modal pada perusahaan publik sektor manufaktur. Jurnal Bisnis dan Akuntansi Vol 13 No 1 April 2011 Hlm 39-56.

Lasut, S. J.D., P. V., \& Raintung, M. C. (2018). Pengaruh Ukuran Perusahaan, Profitabilitas, Dan Likuiditas Terhadap Struktur Modal Pada Perusahaan Otomotif Yang Terdaftar Di Bursa Efek Indonesia Periode 2012-2015. Jurnal EMBA, 6(1), 11-20.

Sugiyono, 2017, Statistika Untuk Penelitian, ALFABETA, Bandung

Suliyanto. 2011. Ekonometrika Terapan: Teori dan Aplikasi dengan SPSS. Yogyakarta.ANDI.

Wang X, Manry D, Rosa G. Ownership Structure, Economic Fluctuation, And Capital Structure: Evidence From China. Int J Fin Econ. 2018;1-14. https://doi.org/10.1002/ijfe.1694

Watiningsih, F. (2018). Pengaruh Profitabilitas, Ukuran Perusahaan, Tangibility, dan Pertumbuhan Terhadap Struktur Modal Pada Perbankan Yang Terdaftar Di BEI Periode 2008-2016. Jurnal Sekuritas, 1(4), 92-105.

Widarjono, Agus. 2018. Ekonometrika : Pengantar dan Aplikasinya. Edisi Keempat. Yogyakarta. UPP STIM YKPN.

Wijaya, E., \& Jessica. (2017). Analisa Pengaruh Struktur Aktiva, Ukuran Perusahaan, Profitabilitas, Growth Opportunity, Tangibility, Bussiness Risk Dan Likuiditas Terhadap Struktur Modal Perusahaan Pada Sektor Property \& Real Estate Yang Terdaftar Di Bursa Efek Indonesia Pada Tahun 201. Jurnal Procuratio, Vol. 5 No. 4.

Wirawan, P. A. (2017). Pengaruh Struktur Aktiva, Profitabilitas, Ukuran Perusahaan dan Likuiditas Terhadap Struktur Modal Pada Perusahaan Sektor Barang Konsumsi Yang Terdaftar Di Bursa Efek Indonesia Periode Tahun 2014- 2015. Jurnal Pendidikan Ekonomi Undiksha, 9(1), 1-10.

Yodha, A, M., S. I., \& Taufik, M. (2018). Profitabilitas, Likuiditas, dan Ukuran Perusahaan Pengaruhnya Terhadap Struktur Modal Pada Perusahaan Blue Chips di Bursa Efek Indonesia Periode 2011-2016. Progress Conference, 1(1), 545-554.

Yunita, S., \& Aji, T. S. (2018). Pengaruh Likuiditas, Tangibility, Growth Opportunity, Risiko Bisnis, dan Ukuran Perusahaan Terhadap Struktur Modal. Jurnal Ilmu Manajemen, 6(4), 409-4016. 